\title{
Impact Of Liquidity On Return On Assets Of Firms: Evidence From Nigeria
}

\author{
Takon Samuel Manyo ${ }^{1}$ (Ph.D.), Vera N. Ogakwu² (Ph.D.) \\ ${ }^{1}$ Caritas University, Enugu, Nigeria \\ ${ }^{2}$ Institute of Development Studies, University of Nigeria, Enugu Campus
}

\begin{abstract}
This study aims at examining the impact of liquidity on Return on Assets on 46 quoted firms listed on the Nigerian Stock Exchange from 2000-2009. Liquidity and its management determine to a great extent the growth and profitability of a firm because inadequate or excess liquidity may be injurious to the smooth operations of the firm. This has become a source of concern for business managers as bank loans are becoming too expensive to maintain as a result of tightening of both the local and international financial market and the reluctance of the public to invest in the shares of companies sequel to the partial crash of the capital market. From the hypothesis test carried out, the result of the study showed that liquidity has a significant positive impact on Return on Assets (ROA), implying that a unit change in liquidity will result into a corresponding increase in ROA. It is concluded therefore that managers can increase profitability by putting in place good credit policy, short cash conversion cycle and an effective cash flow management procedures.
\end{abstract}

KEYWORDS: Working Capital Management, Liquidity management, Corporate profitability, Cash Conversion Cycle

\section{Council for Innovative Research}

Peer Review Research Publishing System

Journal: International Journal of Management \& Information Technology

Vol. 6, No. 3

editor@cirworld.com

www.cirworld.com, member.cirworld.com

\section{INTRODUCTION}


The heart of corporate finance literature is based on long term investment, capital structure and various validation methods. These have been the focus of intention of many researchers in the past. In short, it concerns the long-term financial decisions. On the other hand, it is believed that financial decisions of short-term assets and short-term liabilities management also influence the stock price. These decisions are vital because they demonstrate the financial stability of the firm and the market which develop the perception about the firm accordingly (Afza and Nazir,2008). An efficient working capital management can create value for stakeholders while a deprived policy or inefficient management might affect the business in an appalling way and might cause a financial distress.

Working capital management is among the four cardinal decision areas of financial management, for which every commercially oriented organization has to make (Pandey, 2005). Working capital components of a firm's financial management deals with liquidity aspect of a firm and hence fundamental for the effective and efficient operations as well as the sustainability of its going concern status (Enyi 2006). Working capital and liquidity could mean one and the same thing and relate to the management of current assets and current liabilities of an enterprise. This synonymy is based on the observation that working capital ratios are the most common measures of liquidity (Lamberg and Valming,2009). Liquidity management determines to a large extent the quantity of profit that results as well as the value of shareholders' wealth (Ben-Caleb,2008). For a firm to survive, it must remain liquid as failure to meet its obligations in due time, results in bad credit rating by the short-term creditors, reduction in the value of goodwill in the market and ultimately lead to liquidation(Bhavet 2011). Hence, a good and firm financial management policy seeks to maintain adequate liquidity as to meet its short-term maturing obligations without impairing profitability.

Short term signifies obligations which mature within one accounting year. It also reflects the operating cycle: buying, manufacturing, selling and collecting cash. A firm that is unable to pay its creditors on time and continue to fail its obligations to suppliers of credit, services, and goods can be sick or bankrupt. Inability to meet the short-term liabilities may affect the company's operation and reputation also. Lack of cash or liquid assets on hand may force a company to miss the incentives given by suppliers of credit, services, and goods which result in higher cost of goods and in turn affect the profitability of the business. So there is always a need for the company to maintain certain degree of liquidity. However, there is no standard norm for liquidity. It depends on the nature of the business, scale of operations, location of the business and many other factors.

Every stakeholder has interest in the liquidity position of a company. Suppliers of goods will check the liquidity of the company before selling goods on credit. Employees also have interest in the liquidity as to know whether a company can meet its employees' related obligations in terms of salary, pension, provident fund, etc. Shareholders are interested in understanding the liquidity due to its huge impact on the profitability. They may not like high liquidity as profitability and liquidity are inversely related. However, they are also aware that non-liquidity will deprive the company from getting incentives from suppliers, creditors, and bankers.

Liquidity management is a concept that is receiving serious attention globally mostly with the current financial situations and the state of the world economy. The concern of business owners and managers all over the world is how to devise a better strategy of managing their day to day operations as to meet their obligations as they fall due and increase profitability and shareholders' wealth. Liquidity plays a significant role in the successful functioning of a business firm. Its study is of a major importance to both internal and external analysts due to its close relationship with day-to-day operation of business (Bhunia,2010). Dilemma in liquidity management is to achieve desired trade-off between liquidity and profitability(Rahemen et.al.,2007).

Unfortunately, the principal focus of most organizations is profitability maximization while the need for efficient management of liquid assets is ignored. This approach is justified by the belief that profitability and liquidity are conflicting goals. Hence, a firm can only pursue one at the expense of the other, in consonance with the theory of liquidity and profitability trade-off. On the contrary, Padachi(2006) advised that a firm is required to maintain a balance between liquidity and profitability while conducting its daily operations. This is because both inadequate liquidity and surplus liquidity directly affect profitability (Ogundipe, Idowu and Ogundipe (2012). On the other hand, an insufficient working capital, results in a liquidity crises which is life threatening, and can force a firm into bankruptcy, often with little notice. This also affects the returns of the firm.

Liquidity requirement of a firm depends on the peculiar nature of the firm and there is no specific rule on determining the optimal level of liquidity that a firm can maintain as to ensure positive impact on its profitability.

Certain measures of corporate profitability include Return on Investment(ROI), Return on Equity(ROE) and Return on Assets(ROA). Hence this paper is to investigate the impact of liquidity on return on assets on selected Nigerian firms listed on Nigerian Stock Exchange. Return on assets will all through be used as a measure of profitability. Secondly, the study aims at directing the attention to the importance of active management of liquidity.

To carry out these objectives, the remainder of this paper is organized as follows: section two reviews the literature for relevant theoretical and empirical work on liquidity and its impact on profitability. Section three describes the sample and methodology followed in this study. Section four portrays and discusses the statistical results and their implications. The final section makes some recommendations followed by the conclusion in this study.

\section{LITERATURE REVIEW}

Liquidity is a financial term, that means the amount of capital available for investment. It is the state or condition of a business organization which determines its ability to honor or discharge its maturing obligations made up of current liabilities and long-term debts. Liquidity can also defined as a measure of the relative amount of assets in cash or which 
can be quickly converted into cash without any loss in value available to meet short-term liabilities. Liquidity will help a firm to avoid a situation where a firm will be forced to liquidate with its attendant problems of selling assets at distressed prices and the extra fees paid to lawyers, trustees in bankruptcy and liquidators on liquidation. These definitions above imply that , as liquidity increases, the probability of technical insolvency is reduced.

Liquidity and profitability are the two main purposes of working capital management (WCM) and relates to matching of assets and liabilities movement over time (Lamberge and Valming, 2009). The general claim in literature centers around liquidity/profitability trade off hypothesis which posits that these two financial terms pose conflicting ends to an organization, hence a pursuit of one will mean a trade off of the other (Dash and Hanuman,(2008). However, the other side of thinking holds that managers can pursue both liquidity and profitability goals as these two objectives have a direct relationship. These two views were observed by Chakraborty (2008) when evaluating the relationship between working capital and profitability of Indian pharmaceutical companies. He pointed out that there were two distinct schools of thought on this issue: first that working capital is not a factor of improving profitability and there may be a negative relationship between them. Secondly, that investment in working capital plays a vital role to improve corporate profitability, and unless there is a minimum level of investment of working capital, output and sales cannot be maintained.

A number of studies had supported the liquidity/profitability trade-off theory. In these works, results showed significantly negative association between liquidity management and profitability.

Shin and Soenen (1998) studied a sample of 58985 listed companies in America for a period of twenty years and found a strong negative relationship between the net trade cycle (cash conversion cycle) and corporate profitability. Based on this finding, they concluded that managers can increase the value of their shareholders by reducing the cash conversion period to a reasonable minimum. A similar study was carried out in Athens by Lazaridis and Tryforidis (2006) on 131 listed companies over the period of 2001-2004 to investigate the impact of efficient working capital management on profitability. They used gross operating profit as a measure of profitability with cash conversion cycle, size of the company, fixed financial assets and financial debt ratio as independent variables. They found a strong negative relationship between profitability and cash conversion cycle and advised that managers can create profit for their companies by handling correctly the cash conversion cycle and keeping each component to an optimum level.

On a study to appraise the relationship between working capital and liquidity positions of companies in Nigeria, Etim (2008) adopted the descriptive and explanatory approach to explain the trend of relevant key accounting ratios from the selected companies for the period 2002-2006. Coefficient of correlation was the statistical inference used to establish the nature of the relationship between working capital and liquidity. The study revealed that there was a linear relationship between working capital and liquidity level. Notwithstanding the position of the correlation of the two variables, almost all the companies under study suffered from inadequacy of liquid assets to meet their shot-term financial obligations.

Raheman and Nasir (2007) examined the effect of working capital management on liquidity as well as on profitability of firms in Pakistan. The results showed that a negative relationship exists between variables of working capital management and profitability of the firm. Further study also found a negative relationship between liquidity and profitability and a positive relationship between size of the firm and its profitability and negative relationship between debt used by the firm and its profitability.

Studying on Liquidity, Risk and Profitability analysis, Sharma(2011) discovered that Marunti Suzuki India Itd. is satisfactorily giving out profits and maintaining liquidity position but at increased risk factor. The liquidity position of the company is fluctuating but this is acceptable. He concluded that the company is earning good profit with moderate liquidity.

More recent studies have also confirmed the existence of the trade-off between liquidity and profitability trade-off. Bhunia,et. al.(2011) investigated the liquidity management efficiency and liquidity profitability relationship. The data utilized was extracted from the income statements, balance sheets, and cash flow statements of sampled firms from the India Stock Exchange and CMEI data base. The purposive sample design method was applied in their analysis . Preferred sample of private sector steel companies from 1997-2006 were utilized in the analysis. Results showed that correlation and regression results are positively significant and associated to the firm profitability. Thus, firm manager should concentrate on inventory and receivables with the aim of creating shareholders' wealth.

Bhunia and Brahma(2011) studied the importance of liquidity management on profitability and found a significant negative relationship between the profitability measured in Return on Capital Employed (ROCE) and all independent variables (CR, LR, ALR, DER, AOI, AOD and AOC) except for CR which indicated a positive influence on profitability. An explanation of some of these results could be gleaned from the KPMG (2005) who asserted that shortening the CCC releases liquidity and it impacts on the company's financial position as well as the company's returns.

In Nigeria, Ben-Caleb (2009) studied the relationship between the components of working capital and profitability measured by Return on Assets using a sample of 25 non-financial firms for 2005 and 2006 and found out that only debtors collection period has a significant negative relationship with profitability.

Enyi (2005) observes that present approaches do not take the question of operational size and relative liquidity of the firm into account when dealing with working capital adequacy. The research studied financial reports of 25 selected listed firms together with opinion surveys on (existing) practical applications on working capital management in some of them. The results from the data were validated using students ' $t$ ' distribution test. The findings revealed that firms that considered relative liquidity perform better and have better growth prospect than others. The study recommends the use of relative liquidity for a more accurate estimation of working capital adequacy by organizations. 
Samilogu and Demirgunes (2008) investigated the relationship among Istanbul firms and found that growth in sales affects profitability positively. This result invariably supports the view that liquidity and profitability are directly associated since liquidity is enhanced by sale's growth. Singh and Pandey (2008) suggested that, for the successful working of any business organization, fixed and current assets play a vital role, and that the management of working capital is essential as it has a direct impact on profitability and liquidity.

Lamberg and Valming (2009) studied the impact of liquidity management on profitability during financial crises with a sample of companies listed on Stockholm Stock Exchange's small and mid capitalist with some restrictions. Adopting a quantitative methodology and regression analysis, they found out that the adaptation of liquidity strategies do not have a significant impact on profitability measured by ROA. However, that increased use of liquidity forecasting and short-term financing during the financial crises had a positive impact on ROA. In other words, frequent monitoring and forecasting on liquidity levels and making more short-term investments can provide gains in profitability.

Falope and Ajilore (2007) used a sample of 50 Nigerian quoted non-financial firms for the period 1996-2005. Their study utilized panel data econometrics in a pooled regression where time-series and cross-sectional observations were combined and estimated. They found a significant negative relationship between net operating profitability and average collection period, inventory turnover in days, average payment period and cash conversion cycle for a sample of 50 Nigerian firms listed on the Nigerian Stock Exchange. Furthermore, they found no significant variations in the effects of working capital management between large and small firms.

Vishanani and Shah (2007) studied the impact of working capital management policies on corporate performance on Indian consumer electronic industry by implementing simple correlation and regression models. They found that no established relationship existed between liquidity and profitability for the industry as a whole; but various companies of the industry depicted different types of relationship between liquidity and profitability, although majority of the companies revealed positive association between liquidity and profitability.

Kim, Mauer and Sherman (1998) examined the determinants of corporate liquidity of $915 \cup \mathrm{S}$ industrial firms for the period 1975-1994 by using panel data and different model. They found that firms with large market to book ratio have significantly larger position in liquid assets. In addition, firm size tend to be negatively related to liquidity. Their findings revealed positive relationship between liquidity and cost external financing to the extent that market to book ratio and firm size are reasonable proxies for the cost of external financing. They also found that firms with more volatile earnings and lower return on physical assets relative to those on liquid assets lead to have significantly larger position in liquid assets.

Eljelly(2004) empirically examined the relationship between profitability and liquidity, as measured by current ratio and cash conversion cycle on a sample of 929 joint stock companies in Saudi Arabia. Using correlation and regression analysis, he found significant negative relationship between the firm profitability and liquidity level as measured by current ratio. This relationship is more pronounced for firms with high current ratios and long cash conversion cycles. At the industry level, however, he found that the CCC is of more importance as a measure of liquidity than current ratio that affects profitability. The firm size variable was also found to have a significant effect on profitability at the industry level.

Based on their study on the impact of liquidity ratios on profitability of oil and gas companies in Pakistan,Saleem Rehman (2011) posit that every firm has to maintain the relationship while conducting its day-to-day operations. The results showed that there is a significant impact of only liquid ratio on Return on Assets (ROA) while insignificant on ROE and ROI. The results also showed that ROE is not significantly affected by the three ratios: current ratio, quick ratio, liquid ratio. The main results of the study demonstrate that each ratio (variable) has a significant effect on the financial positions of firms with differing amounts and along with the liquidity ratios in the first place. The study therefore recommended that companies need to maintain adequate liquidity as some portion of the firm's profitability will be shared to the shareholders.

\section{METHODOLOGY}

This study fully relied on historic accounting data collected from the financial statements and accounts of 46 quoted firms (listed) on the Nigerian Stock Exchange from 2000-2009. Ex-post facto research design was adopted for the study. Data from published annual reports and statements of accounts of quoted companies on NSE constitute the most authoritative and accessible documents for assessing the performance of the affected firms .Section 335(2) of Nigerian Companies and Allied Matters Act of 1990 (CAMA) specifies that the balance sheet of a company shall give a true and fair view of the state of affairs of the company as at the end of the year. The data being generated is being employed to run both crosssectional and time-series regression. The sub-sectors where data was generated include: Agriculture/Agro Allied; Airline Services; Aviation; Automobile and Tyre; Breweries; Building Materials; Chemical and Paints; Commercial/Services; Computer and Office Equipment; Conglomerates; Construction; Emerging Markets; Engineering Technology; Footwear; Food/Beverages and Tobacco ; Healthcare; Hotel and Tourism; Industrial/Domestic Products; Information Communication and Telecom; Machinery; Maritime; Media; Packaging; Petroleum; Printing and Publishing; Road Transportation;;Textile. Banking, Mortgage companies and Insurance sub-sectors were excluded due to the nature of their financial reports.

The multiple regression technique was used in analyzing the specified models. The ideas behind regression analysis are the statistical dependence of one variable, the dependent variable in this case, return of assets (ROA), on or more variables, the independent or explanatory variables. Two control variables were also included in the model. These are size and growth.

The general form for a multiple regression analysis is given in the form below: 
$Y=a+b_{1} X_{1}+b_{2} X_{2}+b_{3} X_{3}++$ bn $\mathrm{Xn}+\mathrm{e}$

Where:

$\mathrm{Y}=$ Dependent variable

$\mathrm{a}=$ Constant of the equation

$b_{1}-b n=$ Coefficient of independent variables

$\mathrm{X}_{1}-\mathrm{Xn}=$ Independent variables

$\mathrm{e}=$ Error Term

In the above equation, the constants $b_{1}, b_{2}, b_{3}, \ldots .$. bn determine the slope or gradient of the line and the constant term ' $a$ ' determines the point at which the line crosses the Y-axis , otherwise known as the Y-intercept ( see, Gujarati, 1995).

In order to test our hypothesis which states as follows: Liquidity does not have a positive significant impact on Return on Assets of Nigerian firms, the model could be written as:

ROA $=a+b$ Liquidity $+\log$ Size $+\log$ Growth $+e$

Where

ROA = Return on Assets

a $=$ Constant of the equation

Liq. = Liquidity

logSize $=$ Size ( in logarithm)

log Growth = Growth (in logarithm)

$\mathrm{b}=$ Coefficient of the independent variables

$\mathrm{e}=$ Error term.

Return on Assets (ROA) is used as a measure of firm's profitability ( Nazir and Afza,2009). In other words, ROA is a measure of the overall effectiveness of the firm in generating profit with available assets (Van-Horne and Wachowicz,2005). It is equivalent to Return on Investment (ROI), but more appropriate measure of the operating efficiency of a firm(Pandey,2005). Though there exist various measures of the variable in empirical profitability studies , the most often used in the literature is the Return on Assets. ROA is defined here as :

$$
\frac{\text { Net Income After Taxes }}{\text { Average Book Value Of Assets }}
$$

This variable has been used by Samilogu and Demirgues (2008), Falope and Ajilore (2009), Nazir and Afza(2009), and a lot of others.

Liquidity is used as the independent variable. Liquidity of a firm shows the extent a firm will fulfill its obligation at a shortrun. This study uses current ratio as a measure of a firm's liquidity. It is calculated thus:

$$
\text { Current Ratio }(\mathrm{CR})=\frac{\text { Current Assets }}{\text { Current Liabilities }}
$$

The control variables are size of the firm and growth in sales. Size captures economies of scale and it is believed that as a company becomes larger, it is better placed to reap economies of scale. The study measured Size as the logarithm of total assets as follows :

$$
\text { Size }=\log \text { total assets }
$$

This variable has been used by Gill,et.al.(2010), Alipour (2011),Padachi (2006).

Growth of a firm is measured by variation in its annual sales value with reference to previous year's sales. This ratio is fairly straightforward as follows :

$$
\text { Growth }=\frac{\text { Sales }_{1}-\text { Sales }_{0}}{\text { Sales }_{0}}
$$

Where:

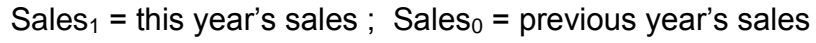

(Falope and Ajilore,2009; Garcia-Teruel and Solano,2007). 


\section{RESULTS AND INTERPRATION}

TABLE 1: SUMMARY OF VARIABLES 2000-2009

\begin{tabular}{|c|c|c|c|c|c|c|c|c|c|c|c|c|c|c|c|c|c|c|c|c|}
\hline Years & Age & $\% \Delta$ & Liquidity & $\% \Delta$ & Leverage & $\% \Delta$ & Growth & $\% \Delta$ & ROA & $\% \Delta$ & CCC & $\% \Delta$ & AR & $\% \Delta$ & AP & $\% \Delta$ & INV & $\% \Delta$ & Size & $\% \Delta$ \\
\hline 2000 & $\begin{array}{l}38 . \\
76\end{array}$ & - & 1.39 & - & .28 & - & .52 & - & .11 & - & 5.78 & - & 87.15 & - & 143.23 & - & 72.35 & - & 7.28 & - \\
\hline 2001 & 39.76 & 2.58 & 1.17 & $\begin{array}{l}- \\
15.83\end{array}$ & .28 & 0.0 & .21 & -59.62 & .13 & 18.18 & 5.85 & 1.21 & 125.52 & 44.03 & 177.74 & 24.09 & 71.41 & -1.30 & 7.36 & 1.10 \\
\hline 2002 & 40.76 & 2.52 & 1.14 & -2.56 & .15 & -46.43 & .04 & 19.05 & .09 & $\overline{3}-77$ & 6.43 & 9.91 & 127.69 & 1.73 & 139.08 & -21.76 & 78.00 & 9.23 & 7.39 & 4.08 \\
\hline 2003 & 40.90 & 3.43 & 1.44 & 26.32 & .18 & 20.00 & .04 & 0.0 & .12 & 33.33 & 6.63 & 3.11 & 127.89 & 1.57 & 139.68 & 4.31 & 78.80 & 1.03 & 7.89 & 6.77 \\
\hline 2004 & 42.76 & 4.55 & .81 & $-\overline{43.75}$ & .25 & 38.89 & 0.91 & 127.5 & .14 & 16.67 & 7.56 & 14.03 & 107.09 & $\overline{16.26}$ & 90.16 & -35.45 & 78.80 & 62.5 & 8.18 & 3.68 \\
\hline 2005 & 43.76 & 2.34 & .87 & 7.41 & .17 & -32.0 & 1.10 & 20.0 & .18 & 28.57 & 7.63 & 9.26 & 90.52 & $\overline{15.47}$ & 106.35 & 17.96 & 128.05 & 19.44 & 8.23 & 6.11 \\
\hline 2006 & 44.76 & 2.29 & .65 & $-\overline{25.28}$ & .09 & -47.05 & 1.01 & -18.19 & .24 & 33.33 & 7.64 & 1.32 & 56.73 & $\begin{array}{l}- \\
37.32\end{array}$ & 234.85 & 120.83 & 152.94 & 14.57 & 8.52 & 3.52 \\
\hline 2007 & 44.96 & 4.47 & .85 & 30.77 & .10 & 11.11 & .80 & -21.72 & .34 & 41.67 & 7.57 & -9.16 & 58.73 & 3.53 & 140.41 & -40.21 & 175.23 & -4.11 & 8.83 & 3.64 \\
\hline 2008 & 46.76 & 4.00 & .88 & 3.53 & .10 & 0.0 & 1.30 & 62.5 & .49 & 44.12 & 7.87 & 3.96 & 58.23 & -8.51 & 140.81 & 2.84 & 174.51 & 1.72 & 9.33 & 5.66 \\
\hline 2009 & 47.74 & 2.09 & 1.16 & 31.82 & .05 & -50.0 & 2.19 & 68.46 & .73 & 48.98 & 7.90 & 3.81 & 52.71 & -9.48 & 125.98 & -10.53 & 174.54 & $\overline{-} 30.92$ & 9.83 & 5.36 \\
\hline Average & & 3.14 & & 12.43 & & -11.72 & & 22.0 & & 26.0 & & 4.16 & & -4.02 & & 6.90 & 120.58 & 8.02 & & 4.44 \\
\hline
\end{tabular}

\section{Source: Firm's Financial Statement 2000 - 2009}

A glance at the above table (table 1) reveals that Return On Assets (ROA) which is a direct measure of profitability and used as the independent variable in the study, had a profit growth of $11 \%$ in 2000 which reduced to $9 \%$ in 2002 and $12 \%$ in 2003 . The profit rose to $14 \%$ in 2004 and drastically rose in subsequent years to $49 \%$ in 2008 . It suddenly rose to $73 \%$ in 2009 . Liquidity rose from $139 \%$ in 2000 to $144 \%$ in 2003 and drastically dropped to $65 \%$ in 2006 with a slight increase to $85 \%$ in 2007 and sharp increase to $116 \%$ in 2009 respectively. Growth which stood at $52 \%$ in 2000 sharply dropped to $4 \%$ in 2003 with a sudden increase to $91 \%$ in 2004 and rose in subsequent years with a tremendous rise to $219 \%$ in 2009 respectively.

Finally there was a steady and impressive increase in size of firms from 7.28 in 2000 to 9.83 in 2009 respectively. 


\section{TABLE 2}

Descriptive Statistics

\begin{tabular}{|l|r|r|r|r|r|}
\hline & \multicolumn{1}{|c|}{$\mathrm{N}$} & Minimum & Maximum & \multicolumn{1}{c|}{ Mean } & Std. Deviation \\
\hline Age & 460 & 38.76 & 47.74 & 43.0726 & 3.00506 \\
Liquidity & 460.00 & .65 & 1.39 & 1.0030 & .22513 \\
Leverage & 460.00 & .05 & .28 & .1616 & .08201 \\
Growth & 460.00 & -.04 & 9.19 & 1.5448 & 3.07741 \\
ROA & 460.00 & .01 & .29 & .0895 & .08351 \\
AR & 460.00 & 52.71 & 127.69 & 89.2665 & 31.34848 \\
AP & 460.00 & 90.16 & 234.85 & 143.7306 & 39.58959 \\
inventory & 460.00 & 71.41 & 175.23 & 122.7168 & 44.84098 \\
Size & 460.00 & 7.28 & 8.53 & 7.9238 & .50014 \\
CCC & 460.00 & 5.78 & 7.63 & 6.9131 & .78572 \\
\hline
\end{tabular}

Sources: Computed from Data from Annual Reports of Quoted Companies

Table 2 presents a descriptive statistics of the study for 46 firms (2000-2009) for a total observation of 460 firm-years. The main variables for this study is the ROA (which is the dependent variable), Liquidity (the independent variable) and the control variables made up of size and growth respectively. All variables were calculated using the balance sheet (book) values. Moreover, the measurement of profitability could only be based on income statement values, not on so -called market values. When market values are considered in studies, there is always rather legitimate question of the date for which the 'market value' refer. Hence the study relied on 'book values' as at the date of the financial report.

From the table, liquidity has a $1.003(100 \%$ ) average with a minimum of $65 \%$ maximum of $139 \%$ and SD of 0.225 . Growth has a mean of 1.54 with a minimum and maximum of -0.04 and 9.19 with a SD of 3.08, while Return on Assets has an average of $8 \%$, a minimum and maximum of $1 \%$ and $29 \%$ with SD of 0.08 respectively. The mean of $\mathrm{ROA}(0.0895)$ shows that Nigerian companies, by considering inflation rate, have poor performance over the study period of 2000-2009. Finally, size has an average of 7.92 with minimum and maximum of 7.28 and 8.53 with SD as 0.50 respectively.

\section{TABLE 3}

Correlations

\begin{tabular}{|c|c|c|c|c|c|c|c|c|c|c|c|}
\hline & & $\mathrm{ROA}$ & SIZE & LIQUIDITY & LEVERAGE & INVENTORY & GROWTH & $\mathrm{CCC}$ & AGE & ACCTR & ACCP \\
\hline $\mathrm{ROA}$ & $\begin{array}{l}\text { Pearson Correlation } \\
\mathrm{N}\end{array}$ & $\begin{array}{r}1 \\
10\end{array}$ & & & & & & & & & \\
\hline SIZE & $\begin{array}{l}\text { Pearson Correlation } \\
\text { Sig. (2-tailed) } \\
\mathrm{N}\end{array}$ & $\begin{array}{r}.201 \\
.577 \\
10\end{array}$ & $\begin{array}{r}1 \\
10\end{array}$ & & & & & & & & \\
\hline LIQUIDITY & $\begin{array}{l}\text { Pearson Correlation } \\
\text { Sig. (2-tailed) } \\
\mathrm{N}\end{array}$ & $\begin{array}{r}.791 \\
.004 \\
10\end{array}$ & $\begin{array}{r}.697 \\
.025 \\
10\end{array}$ & $\begin{array}{r}1 \\
10 \\
\end{array}$ & & & & & & & \\
\hline LEVERAGE & $\begin{array}{l}\text { Pearson Correlation } \\
\text { Sig. (2-tailed) } \\
\mathrm{N}\end{array}$ & $\begin{array}{r}.010 \\
.979 \\
10 \\
\end{array}$ & $\begin{array}{r}-.658 \\
.039 \\
10 \\
\end{array}$ & $\begin{array}{r}.419 \\
.228 \\
10 \\
\end{array}$ & $\begin{array}{r}1 \\
10 \\
\end{array}$ & & & & & & \\
\hline INVENTORY & $\begin{array}{l}\text { Pearson Correlation } \\
\text { Sig. (2-tailed) } \\
\mathrm{N}\end{array}$ & $\begin{array}{r}-.294 \\
.409 \\
10\end{array}$ & $\begin{array}{r}.869 \\
.001 \\
10\end{array}$ & $\begin{array}{r}-.870 \\
.001 \\
10\end{array}$ & $\begin{array}{r}-.606 \\
.063 \\
10\end{array}$ & $\begin{array}{r}1 \\
10\end{array}$ & & & & & \\
\hline GROWTH & $\begin{array}{l}\text { Pearson Correlation } \\
\text { Sig. (2-tailed) } \\
\mathrm{N}\end{array}$ & $\begin{array}{r}.945 \\
.000 \\
10\end{array}$ & $\begin{array}{r}.484 \\
.157 \\
10\end{array}$ & $\begin{array}{r}.097 \\
.790 \\
10\end{array}$ & $\begin{array}{r}-.239 \\
.505 \\
10\end{array}$ & $\begin{array}{r}.006 \\
.986 \\
10\end{array}$ & $\begin{array}{r}1 \\
10\end{array}$ & & & & \\
\hline CCC & $\begin{array}{l}\text { Pearson Correlation } \\
\text { Sig. (2-tailed) } \\
\mathrm{N}\end{array}$ & $\begin{array}{r}-.722 \\
.028 \\
10\end{array}$ & $\begin{array}{r}.758 \\
.011 \\
10\end{array}$ & $\begin{array}{r}-.485 \\
.155 \\
10\end{array}$ & $\begin{array}{r}-.265 \\
.459 \\
10\end{array}$ & $\begin{array}{r}.648 \\
.043 \\
10\end{array}$ & $\begin{array}{r}.298 \\
.403 \\
10\end{array}$ & $\begin{array}{r}1 \\
10\end{array}$ & & & \\
\hline AGE & $\begin{array}{l}\text { Pearson Correlation } \\
\text { Sig. (2-tailed) } \\
\mathrm{N}\end{array}$ & $\begin{array}{r}.807 \\
.022 \\
10\end{array}$ & $\begin{array}{r}.938 \\
.000 \\
10\end{array}$ & $\begin{array}{r}.577 \\
.081 \\
10\end{array}$ & $\begin{array}{r}-.826 \\
.003 \\
10\end{array}$ & $\begin{array}{r}.792 \\
.006 \\
10\end{array}$ & $\begin{array}{r}.484 \\
.156 \\
10\end{array}$ & $\begin{array}{r}.624 \\
.054 \\
10\end{array}$ & 1 & & \\
\hline ACCTR & $\begin{array}{l}\text { Pearson Correlation } \\
\text { Sig. (2-tailed) } \\
\mathrm{N}\end{array}$ & $\begin{array}{r}-.885 \\
.015 \\
10\end{array}$ & $\begin{array}{r}-.793 \\
.006 \\
10\end{array}$ & $\begin{array}{r}.424 \\
.222 \\
10\end{array}$ & $\begin{array}{r}.640 \\
.046 \\
10\end{array}$ & $\begin{array}{r}-.773 \\
.009 \\
10\end{array}$ & $\begin{array}{r}-.304 \\
.394 \\
10\end{array}$ & $\begin{array}{r}-.419 \\
.229 \\
10\end{array}$ & $\begin{array}{r}-.799 \\
.006 \\
10\end{array}$ & 10 & \\
\hline ACCP & $\begin{array}{l}\text { Pearson Correlation } \\
\text { Sig. (2-tailed) } \\
\mathrm{N}\end{array}$ & $\begin{array}{r}-.432 \\
.212 \\
10\end{array}$ & $\begin{array}{r}-.143 \\
.693 \\
10\end{array}$ & $\begin{array}{r}.178 \\
.623 \\
10\end{array}$ & $\begin{array}{r}-.174 \\
.631 \\
10\end{array}$ & $\begin{array}{r}.110 \\
.763 \\
10\end{array}$ & $\begin{array}{r}-.387 \\
.270 \\
10\end{array}$ & $\begin{array}{r}. .651 \\
.041 \\
10\end{array}$ & $\begin{array}{r}-.043 \\
.907 \\
10\end{array}$ & $\begin{array}{r}-.200 \\
.580 \\
10\end{array}$ & 1 \\
\hline
\end{tabular}

Source: SPSS Output on Firms' Annual Report 2000 - 2009 
Table 3 displays Pearson Correlation Matrix among the variables concentrating on the relationship between dependent and independent variables. Correlation explains how two different variables react to each other eg. what change will occur in one variable with the change in the other variable.

From the table, size in the firms related positively with ROA indicating that if firm increases its size of sales, it will lead to increase in profitability. Liquidity of the firm correlated positively with profitability (ROA) showing that when firms invest their liquid assets very well, high returns will be generated. Apart from size, liquidity ,leverage, growth and age, other variables have a negative relationship with profitability.

As earlier stated, the hypothesis for this study is : Liquidity does not have a positive significant impact on Return on Assets of Nigerian firms. To test this hypothesis, it is restated in null and alternative form as:H0:Liquidity does not have a positive significant impact Return on Assets of Nigerian firms.

Ha: Liquidity has a positive significant impact on Return on Assets of Nigerian firms.

The decision rule is as follows: 1 . Accept $\mathrm{Ho}$ and reject $\mathrm{Ha}$ if the variable of has a negative coefficient sign and $\mathrm{p}<0.05$.

2. Accept $\mathrm{Ha}$ and reject $\mathrm{Ho}$ if the variable of liquidity has a positive coefficient sign and $\mathrm{p}<0.05$.

\section{TABLE 4 : TEST OF HYPOTHESIS}

Dependent Variable: $\operatorname{LOG}(\mathrm{ROA})$

Method: Least Squares

Date: 06/04/12 Time: 00:09

Sample: 110

Included observations: 8

Excluded observations: 2

White Heteroskedasticity-Consistent Standard Errors \& Covariance

\begin{tabular}{|c|c|c|c|c|}
\hline Variable & Coefficient & Std. Error & t-Statistic & Prob. \\
\hline C & -0.305504 & 3.744748 & -0.081582 & 0.9389 \\
\hline LIQUIDITY & 0.882350 & 0.664631 & 5.327579 & 0.0250 \\
\hline LOG SIZE & -0.362259 & 0.408356 & -0.887115 & 0.4251 \\
\hline LOG(GROWTH) & 0.425088 & 0.062459 & 6.805865 & 0.0024 \\
\hline R-squared & 0.910438 & Mean d & ident var & 2.779884 \\
\hline Adjusted R-squared & 0.843267 & S.D. de & lent var & 1.088531 \\
\hline
\end{tabular}

$\begin{array}{llll}\text { Adjusted R-squared } & 0.843267 & \text { S.D. dependent var } & 1.088531 \\ \text { S.E. of regression } & 0.430944 & \text { Akaike info criterion } & 1.461175 \\ \text { Sum squared resid } & 0.742851 & \text { Schwarz criterion } & 1.500896 \\ \text { Log likelihood } & -1.844701 & \text { F-statistic } & 13.55400 \\ \text { Durbin-Watson stat } & 1.734077 & \text { Prob(F-statistic) } & 0.014583\end{array}$

Source: Firms' Annual Report 2000 - 2009 (E-View Output)

\section{RESULTS AND IMPLICATIONS}

The linear regression result shows that the coefficient of determination, $R^{2}(91 \%)$ indicates that almost all the variations that exist in the dependent variable are explained by the model. The significant value of the $\mathrm{F}-$ statistic is less than 0.05 , which means that variation which is being explained by the model is not due to chance $(f=13.55, P<0.05)$. The independent variable (liquidity), has significant impact on Return on Assets (ROA); (Coefficient of liquidity $=0.88$; $t=$ 
$5.33 ; P=0.025 ; P<0.05)$. This implies that a unit change in liquidity will result into a corresponding $2.8 \%$ increase in $R O A$. Size has no significant impact on ROA, (Coefficient of Size $=-0.36 ; t=-0.89 ; P=0.43 ; P>0.05$ ), while growth has a positive significant impact on ROA ( Coefficient of growth $=0.43 ; t=6.81 ; P=0.002 ; P<0.05$ ).

The Durbin - Watson (D-W) is 1.73, showing an acceptable level of autocorrelation. The $D-W$ statistics is always between 0 and 4 . A value of 2 shows complete absence of autocorrelation .

\section{DECISION:}

Since the coefficient of liquidity has a positive sign $(0.882350)$ and $p$-value is $0.0250(p<0.05)$, we accept the alternative hypothesis and reject the null hypothesis. The regression model becomes: ROA $=0.31+0.88 \mathrm{LIQ}-0.36 \mathrm{SIZE}+$ $0.43 G R O W T H$. We can say that liquidity has a positive significant impact on Return on Assets of Nigerian firms. This is in fact a contravention of our theoretical foundation ( liquidity - profitability trade-off theory ) which posits that profitability and liquidity are inversely related or that there must always be a trade-off between profitability and liquidity.

The implication of the result is that cash conversion cycle (CCC) is measuring liquidity differently from conventional ratio. Generally, traditional liquidity ratios like current ratio have been understood to have lack in measuring the efficiency of firms' working capital management. This result agrees with the findings of Sayaddzaman (2006), Lyroudi and Lazaridis (2000), Bhunia,et.al. (2011) ,and Pandey and Jaiswal (2011).

A further implication is that liquidity had low degree of influence on the profitability of manufacturing companies in Nigeria within the period studied. This was also to be expected, given the weak state of many manufacturing companies in Nigeria.

\section{RECOMMENDATIONS AND CONCLUSION}

From the above results, it is recommended that firms should work towards improving their overall state of liquidity so as to have a favorable returns on profitability. They should have a more realistic credit policy which would narrow the gap minimization of cash flows as well as the reduction of cash conversion period which has the potential of improving liquidity.

The importance of liquidity management in any organization cannot be overemphasized. The reason is that either inadequate or excess liquidity may be injurious to the smooth operations of the organization. This study explored the impact of liquidity on profitability (measured by Return on Assets). From literature, the controversy as regards the relationship and impact of liquidity on profitability is yet to be resolved as divergent findings exist. This empirical investigation however shows that liquidity has a positive significant impact on return on assets (as an index of profitability).

It is suggested that further research be conducted on the same topic with more sectors with an extension of its scope.

\section{REFERENCES}

[1] Afza, T. and Nazir, M.S. (2008). "Working Capital Approaches and Firm's Return" ,Pakistan Journal of Commerce and Social Sciences, 1(1) ISSN 19978553 pp 25-36.

[2] Bhavet, E.(2011). "Management of Liquidity-A Case Study of Tisco Ltd.," International Journal of Research in IT \&Management 149 IJRIM vol.1(2) (ISSN)2231-4334).

[3] Bhumia,A. and Brahuma, S.B.(2011). "Importance of Liquidity Management on Profitability" ,Asian Journal of Business Management,3(2) : 108-117, ISSN 2041-8752. Accessed:May 15,2011.

[4] Bhunia, A.(2010). "A Trend Analysis of Liquidity Management Efficiency in Selected Private Sector, Indian Steel Industry" , International Journal of Research in Commerce and Management 1(5) pp.213.

[5] Chakraborty, K.(2008). "Working Capital and Profitability: An Empirical Analysis of Their Relationship with reference to Selected companies in the Indian Pharmaceutical Industry", the Icfai Journal of Management Research, vol.34.

[6] Dash,M. and Hanuman,R. (2008). "A Liquidity -Profitability Trade-Off Model for Working Capital Management “. Retrieved from http:// ssrm.com/abstract $=1408722$.

[7] Eljelly,A.(2004). "Liquidity - Profitability Trade off : An Empirical Investment in an Emerging Market",International Journal of Commerce and Management,14(2) 48-61.

[8] Enyi, P.E. (2005). "Applying Relative Solvency to Working Capital Management - The Break - Even Approach", Social Science Research Network, pp.1 -21. Accessed on 1/1/2004.

[9] Etim, E.O. (2008). "Relationship Between Working Capital and Liquidity Position of Nigerian Companies : A Study of Ten Selected Companies ", International Journal of Investment and Finance,1(1\&2).

[10] -FalopeO. I. and Ajilore, O. (2009). "Working Capital Management and Corporate Profitability : Evidence from Panel Data Analysis of Selected Quoted Companies in Nigeria" ,Research Journal of Business Management ,3(3) p.73-84.

[11] Garcia-Teruel,P.J. and Matinez-Solano,(2007). "Effects of Working Capital Management on SME Protability" , International Journal of Management Finance,vol.3 No.3 pp164-177. 
[12] Gujarati,D.N.(1995). Basic Econometrics, McGrowHill, International Edition, Economic series.

[13] Kim,C. Soo, Mauer, D.C.and Sherman, A.E.(1998). "The Determinants of Corporate Liquidity: Theory and Evidence", Journal of Financial and Quantitative Analysis,33(3).

[14] KPMG,(2005). "Working Capital Management Survey:How European Companies Manage Their Working Capital".KPMG international.

[15] Lamberg, S. and Valming, S.(2009). "Impact of Liquidity Management and Profitability: A Study of the Adaptation of Liquidity Strategies in Financial Crises" Umea School of Business.

[16] Ben - Caleb, E.(2009). "WOrking Capital Management and Profitability of listed Companies in Nigeria” ,Nigerian Research Journal of Accountacy,vol.1(1) pp.44-57.

[17] Lazaridis, L. and Tryforidis,D.(2006). "The Relationship Between Working Capital and Profitability of Listed Companies in the Athens Stock Exchange", Journal of Financial Management and Analysis, 1(19),26-35.

[18] Lyroudi, K. and Lazaridis, J.(2000). "The Cash Conversion Cycle and Liquidity: An Analysis of the Food Industry in Greece" ,EFMA 2000 Athens from http;// ssrn.com /paper =236175.

[19] Nazir ,M.S. and Afza , T.(2009). "Working Capital Requirements and the Determining Factors in Pakistan”, ICFAI Journal of Applied Finance,15(4) pp.28 -38.

[20] Ogundipe, S.E.,Idowu.A. and Ogundipe, L.O.(2012). "Working Capital Management ,Firms' Performance and Market Valuation in Nigeria", International Journal of Social and Human Sciences,6,pp.143 -147.

[21] Padachi , K.(2006). "Trends in Working Capital Management and its Impact on Firm's Performance: Analysis of Mauritanian Manufacturing Firms" , International Review of Business Research Papers 2(2) 45-48.

[22] Pandey,I.M.(2005). Financial Management (9 $9^{\text {th }}$ Edition) New Delhi, Vikas Publishing House PVT Ltd.

[23] Pandey,S.and Jaiswal, V.K.(2011). "Effectiveness on Profitability: Working Capital Management", SCMS Journal of Indian Management.

[24] Raheman,A. and Nasir,M.(2007). "Working Capital Management and Profitability - Case of Pakistan Firms" International Review of Business Research Papers,3(1),279-300.

[25] Rahemen A. and Nasir , M. (2007). "Working Capital Management and Profitability-Case of Pakistan Firms" ,International Review of Business Papers vol.3 no.1.

[26] Saleem,Q.and Rehaman R.U.(2007). "Working Capital Management and Profitability-Case of Pakistan Firms", Interdisciplinary Journal of Research in Business vol.1(7).

[27] Samilogu,F. and Demirgunes, K.(2008). "The Effect of Working Capital Management on Firm Profitability : Evidence from Turkey", The International Journal of Applied Economics and Finance,2(1) pp44-50.

[28] Sayaduzzaman, M.(2006). "Working Capital Management: A Study of British American Tobacco Bangladesh Company Ltd" ,The Journal of Nepalese Business Studies, 3(1) pp.78-84.

[29] Shin,H. and L.A.Soenen(1998) "Efficiency of Working Capital Management and Corporate Profitability", Financial Practice and Education, vol.8.no.2pp.37-45.

[30] Singh, J.P.and Pandey,S.(2008). "Impact of Working Capital in the Profitability of Hindaloo Industries Limited" Icfai University Journal of Financial Economics ,6(4),62-72.

[31] Van-Horne, J.C. and Wachowicz, J.M.(2005). Fundamentals of Financial Management,(12 ${ }^{\text {th }}$ Edition), Prentice Hall Publishers, New York.

[32] Vishnani,S., and Shah,B.K.(2007). "Impact of Working Capital Management Policies on Corporate Performance: An Empirical Study , Global Business Review,8(2),pp267-281. 